\title{
Absolute Humidity Measurements Using Two Parallel Plate lonization Chambers with $\boldsymbol{a}$-Ray Sources
}

\author{
Shigeaki MATSUMOTO and Hisanobu KoBAYASHI \\ Laboratory of Applied Physics, Faculty of Engineering, Saitama University \\ Urawa, Saitama-Pref. 338, Japan \\ Received March 23, 1988
}

\begin{abstract}
Two parallel plate ionization chambers $A$ and $B$ were constructed to remove the wall effect and the polarity effect. The air in chamber $A$ was kept dry and the air in chamber $B$ was regulated at various humidities and then the differences in the ionization currents between the chambers $A$ and $B$ were measured in the absolute humidity ranging up to $30 \mathrm{~g} / \mathrm{m}^{3}$ ( $80 \%$ in relative humidity at $35{ }^{\circ} \mathrm{C}$ ) in the atmospheric pressure. The differences were converted into the values at the constant temperature and pressure because the differences were due to the amount of recombination of positive and negative ions generated by water vapor and the amount was proportional to the square of the pressure divided by the temperature. The relation between the difference converted and the absolute humidity was obtained and was almost independent of the temperature and the atmospheric pressure. The absolute humidity could be measured with an accuracy of $2 \%$.
\end{abstract}

Key Words: alpha-ray, ionization chamber, absolute humidity

\section{Introduction}

It has been reported by Burbidge and Alexander ${ }^{1)}$ that the ionization current caused by $\alpha$-rays decreased slightly due to the humidity. The further works applied to the humidity measurements have not be done because the decrease due to the humidity was too slight.

The relative humidity measurements using a double cylindrical ionization chamber with $\alpha$ rays have been recently reported by the authors $^{2), 3)}$. The differences in the ionization currents between dry air and humid air were proportional to the relative humidity in the temperature ranging from 10 to $35^{\circ} \mathrm{C}$. However, there were the disadvantages in the double chamber that the characteristic curves of the chambers were affected significantly by the wall effects and by the polarity effects of the electrode and therefore the effects of the temperature and the atmospheric pressure could not be stably removed.

Two parallel plate ionization chambers are used in the present paper to remove the disadvantages mentioned above.

\section{Experimental Apparatus}

Two parallel plate ionization chambers A and $\mathbf{B}$ were constructed to remove the wall effect and the polarity effect.

The construction of two parallel plate ionization chambers was entirely same as shown in Fig. 1. The outer diameters of the collecting electrode, the guard ring and the high voltage electrode were $120 \mathrm{~mm}, 180 \mathrm{~mm}$ and $170 \mathrm{~mm}$, respectively. The $\alpha$-ray source of ${ }^{241} \mathrm{Am}$, about $37 \mathrm{kBq}(1 \mu \mathrm{Ci})$ which size was $2 \mathrm{~mm} \times 3 \mathrm{~mm}$ was placed at the center of the high voltage electrode. The distance between the two electrodes was fixed at $50 \mathrm{~mm}$ which was much longer than the range of $\alpha$-rays to remove the wall effects.

The experimental apparatus is shown in Fig. 2. Two parallel plate ionization chambers were placed in a cubic box made of copper plate in which the temperature was controlled from 10 to $35^{\circ} \mathrm{C}$ within an accuracy of $\pm 0.5^{\circ} \mathrm{C}$. The air in chamber A was kept dry to be assumed $0 \%$ humidity with silica gel placed in the chamber. The humidity in the chamber B was regulated at $0 \%, 11 \%, 43 \%$ and $75 \%$ 

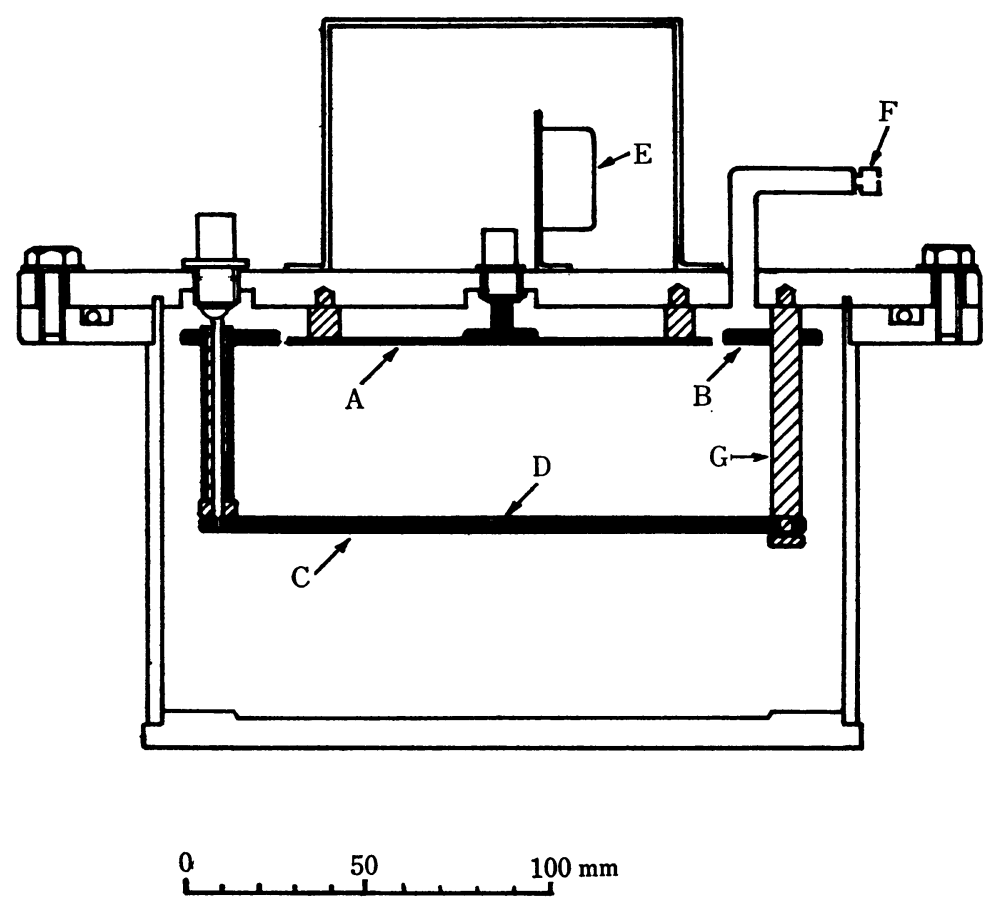

Fig. 1 Construction of the parallel plate ionization chamber A: Collecting electrode; B: Guard ring; C: High voltage electrode; D: $\alpha$-ray source, ${ }^{241} \mathrm{Am}$; E: Operational amplifier; F: Cap with a pin hole; G: Insulator.

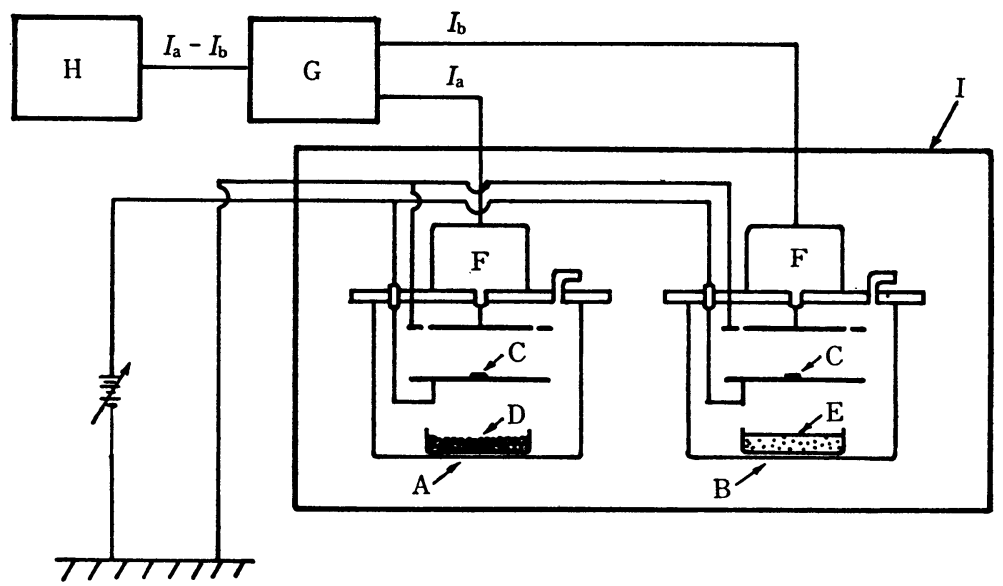

Fig. 2 Sch:matic diagram of the experimental apparatus for the humidity measurements.

A: Chamber A; B: Chamber B; C: $\alpha$-ray source; D: Silica gel; E: Silica gel or saturated salt solutions of lithium chloride, potassium carbonate and sodium chloride; F: Operational amplifier; G: Differencial amplifier; H: Penrecorder; I: Temperature regulated box.

in relative humidity by silica gel and the saturated salt solutions such as lithium chloride, potassium carbonate and sodium chloride, respectively. Silica gel or the saturated salt solution was put in the petri dish and placed in the chamber. The above relative humidity range 
was from 0 to $30 \mathrm{~g} / \mathrm{m}^{3}$ in absolute humidity. The high voltage of positive polarity was applied to both chambers by a dry battery to remove the polarity effect. The ionization currents of both chambers were measured by the operational amplifiers $(4 \mathrm{M} / 7529)$ with the feedback high resistances of $10^{10} \Omega$. The time constant of the amplifiers was set at $50 \mathrm{~s}$. The differences in the ionization currents between chambers $\mathbf{A}$ and $\mathbf{B}$ were measured by a differencial circuit at various humidities and also were recorded by a pen recorder.

\section{Experimental Results}

The ionization currents of the chamber B vs. the applied voltage were measured as shown in Fig. 3 when the air in the chamber was regulated at $0 \%$ and $75 \%$ in relative humidity at $20^{\circ} \mathrm{C}$ in the atmospheric pressure. The difference in the ionization currents is considered to be due to the recombination of positive and negative ions generated by water vapor.

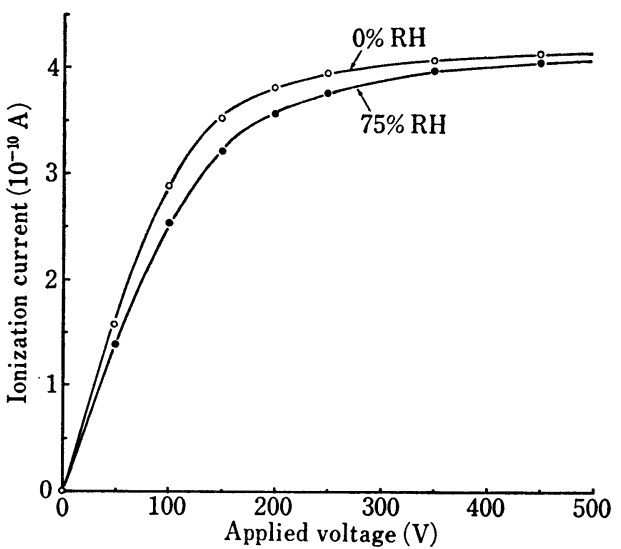

Fig. 3 Ionization current vs. applied voltage in chamber $B$ when the air in the chamber was regulated at $0 \%$ and $75 \%$ in relative humidity $(\mathrm{RH})$ at $20^{\circ} \mathrm{C}$ in the atmospheric pressure.

The ionization currents of the chamber A in dry air vs. the applied voltage were also measured and almost equal to that of the chamber B. The differences in the ionization currents between the chambers $A$ and $B$ were recorded at various humidities against time at $20^{\circ} \mathrm{C}$ and $1026 \mathrm{mb}$ in the atmospheric pressure

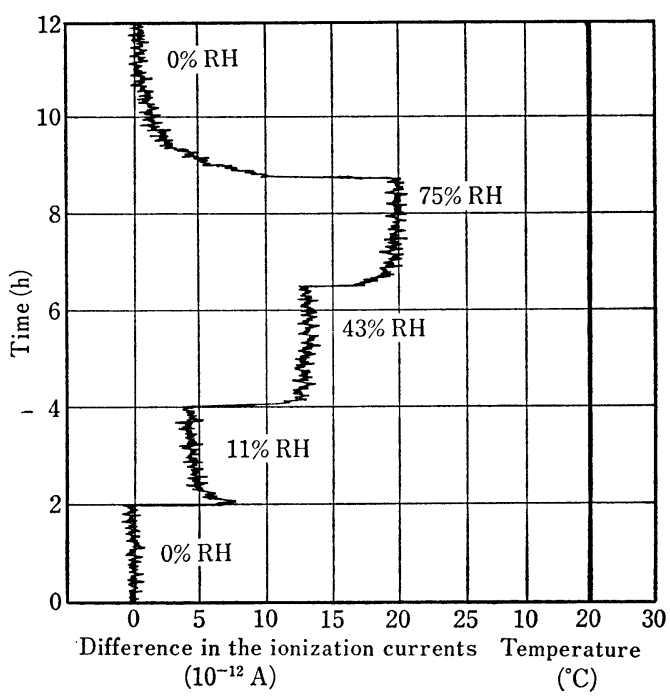

Fig. 4 The differences in the ionization currents between chambers $\mathrm{A}$ and $B$ were recorded against time at $20^{\circ} \mathrm{C}$ in the atmospheric pressure. The air in the chamber A was kept dry and the air in the chamber B was regulated at $0 \%, 11 \%, 43 \%$ and $75 \%$ in relative humidity.

as shown in Fig. 4, where a potential of $250 \mathrm{~V}$ was applied to both chambers.

The relations between the difference in the ionization currents and the relative humidity at the temperatures of 10,20 and $35^{\circ} \mathrm{C}$ were obtained as shown in Fig. 5. The differences were proportional to the relative humidity.

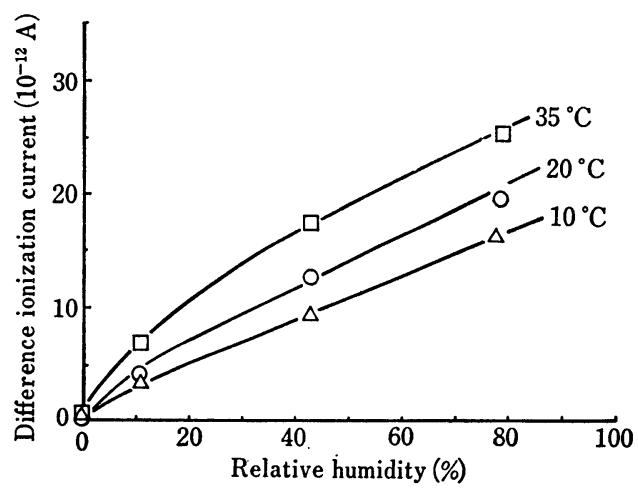

Fig. 5 Relation between the difference in the ionization currents and the relative humidity at the temperatures of 10,20 and $35{ }^{\circ} \mathrm{C}$ 


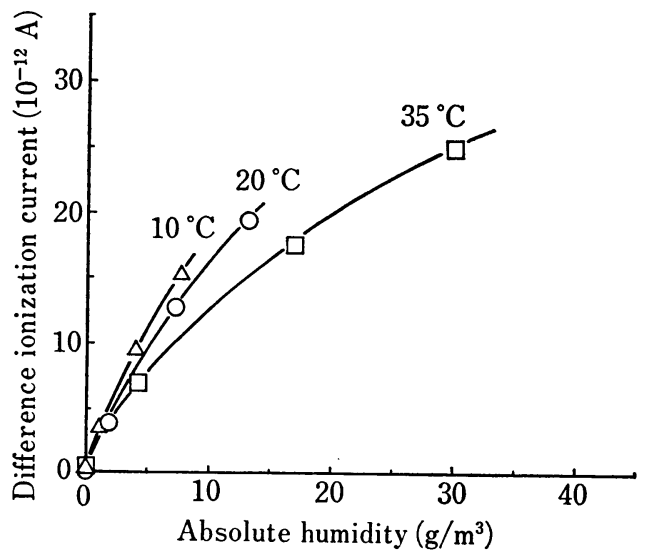

Fig. 6 Relation between the difference in the ionization currents and the absolute humidity at the temperatures of 10,20 and $35^{\circ} \mathrm{C}$.

The relations between the difference in the ionization currents and the absolute humidity calculated from the relative humidity at each temperature were obtained as shown in Fig. 6. The differences were proportional to the absolute humidity, however the slope of each line was different at each temperature in this figure.

Here, the amount of recombination per unit volume and unit time is generally given by the expression $\beta n^{+} n^{-}$where $n^{+}$and $n^{-}$are the densities of positive ions and negative ions generated by water vapor respectively and $\beta$ is the recombination constant. Both densities are inversely proportional to the absolute temperature $T$ and are proportional to the atmospheric pressure $P$. Then the amount of recombination is proportional to the square of the pressure divided by the temperature, $(P / T)^{2}$. The differences in the ionization currents which were due to the amount of recombination were converted into the values corresponding to $10^{\circ} \mathrm{C}$ and $1026 \mathrm{mb}$. The relation between the difference converted in the ionization currents and the absolute humidity is shown in Fig. 7. The difference converted was almost independent of the temperatures and pressures. The mean error of $\pm 0.4 \mathrm{~g} / \mathrm{m}^{3}$ was obtained in the absolute humidity ranging up to $30 \mathrm{~g} / \mathrm{m}^{3}$. Therefore, the absolute humidity could be measured with an accuracy of $2 \%$ in the temperature ranging from 10 to $35^{\circ} \mathrm{C}$.

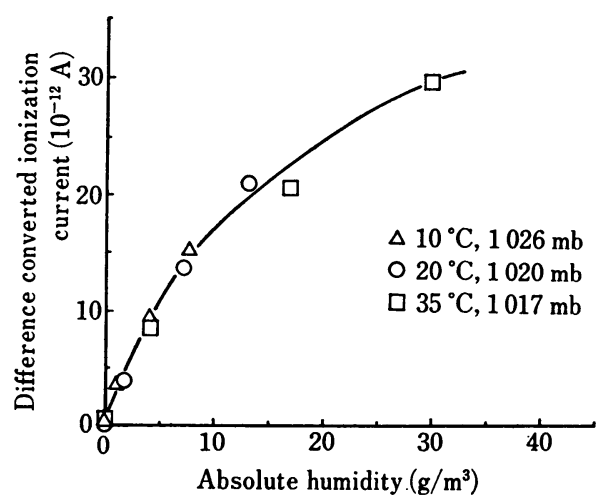

Fig. 7 Relation between the difference in the ionization currents converted into the values corresponding to $10^{\circ} \mathrm{C}$ and $1026 \mathrm{mb}$ and the absolute humidity.

\section{Conclusion}

Two parallel plate ionization chambers A and $B$ were constructed to remove the wall effect and the polarity effect. The air in chamber A was kept dry and the air in chamber B was regulated at various humidities and then the differences in the ionization currents between the chambers A and B were measured in the absolute humidity ranging up to $30 \mathrm{~g} / \mathrm{m}^{3}$ $\left(80 \%\right.$ in relative humidity at $\left.35^{\circ} \mathrm{C}\right)$ in the temperature ranging from 10 to $35^{\circ} \mathrm{C}$ and in the atmospheric pressure. The amount of recombination of positive and negative ions generated by water vapor is proportional to the product of positive and negative ion densities which are inversely proportional to the temperature $T$ and are proportional to the pressure $P$. Then the difference in the ionization currents which was due to the amount of recombination was proportional to $(P / T)^{2}$. Therefore, the differences in the ionization currents were converted into the values at the constant temperature and pressure. The relation between the difference converted in the ionization currents and the absolute humidity was obtained and was almost independent of the temperature and the atmospheric pressure. The absolute humidity could be measured with an accuracy of $2 \%$ in the ranging up to 30 $\mathrm{g} / \mathrm{m}^{3}, 80 \%$ in relative humidity at $35^{\circ} \mathrm{C}$. 


\section{References}

1) Burbidge, B.W. and Alexander, N.S.: Proc. Phys. Soc. (London), 40, 149-153 (1927)
2) Matsumoto, S. and Kobayashi, H.: Nucl. Instr. Meth., 184, 603-604 (1981)

3) Matsumoto, S. and Kobayashi, H.: ibid., A255, 290-292 (1987)

要

旨

\title{
二つの平行板型差動電離箱 ( $\boldsymbol{a}$ 線内蔵)を用いた絶対湿度の測定
}

\author{
松本茂昭, 小林久信 \\ 埼玉大学工学部応用物理学講座 \\ 338 埼玉県浦和市下大久保 255
}

$\alpha$ 線の電離電流が湿度により数\%減少することを利用して湿度測定を行った。電離箱の一方を湿 度約 $0 \%$ に保ち, 他方を種タ湿度に調整し, 二つの電離電流の差を求め温度拈よび気圧の補償を行 った。壁勃果と極性効果を除くため平行板型電離箱にし, 差電流と相対湿度との関係を求めた。さ らに，再結合に怙ける正負イオン密度の補正を行い差電流から精度 $2 \%$ 絶対湿度を求めることが できた。 